\title{
Weight, Dietary Behavior, and Physical Activity in Childhood and Adolescence: Implications for Adult Cancer Risk
}

\author{
Bernard F. Fuemmeler ${ }^{\mathrm{a}} \quad$ Margaret K. Pendzich $^{\mathrm{a}} \quad$ Kenneth P. Tercyak $^{\mathrm{b}}$ \\ ${ }^{a}$ Department of Community and Family Medicine, Duke University Medical Center, Durham, NC, \\ ${ }^{\mathrm{b}}$ Departments of Oncology and Pediatrics, Georgetown University Medical Center, Washington DC, USA
}

\section{Key Words \\ Children · Weight · Diet · Physical activity · Cancer Obesity · Tracking}

\section{Summary}

Lifestyle factors related to energy balance, including weight, dietary behavior and physical activity, are associated with cancer risk. The period of childhood and growth into adolescence and early adulthood may represent a 'cumulative risk' for later adult-onset cancers. We review a number of epidemiologic studies that have examined associations among childhood and adolescent body size, diet, and physical activity with adult cancer risk. These studies suggest that unhealthy behaviors that develop early in life and persist over time may increase the risk of some cancer types, such as premenopausal breast, ovarian, endometrial, colon and renal cancer, adversely affect cancer-related morbidities, and increase mortality. Continued research is needed to further determine and refine how timing and degree of such exposures in early childhood and adolescence relate to adult cancer risk. Presently, sufficient evidence suggests a continued need for stronger primary prevention in cancer and obesity research via modified lifestyle behaviors earlier in the developmental spectrum, i.e. during childhood and adolescence.

\section{Introduction}

The rising rates of obesity both globally and in the USA are of high public health significance because of the burden that obesity has on society in terms of economic costs, loss of productivity, disability, and overall mortality $[1,2]$. The relationship between overweight $\left(\mathrm{BMI}=25-29.9 \mathrm{~kg} / \mathrm{m}^{2}\right)$ or obesity $\left(\mathrm{BMI} \geq 30 \mathrm{~kg} / \mathrm{m}^{2}\right)$ and childhood morbidities or adult chronic diseases has been widely studied. A growing set of studies have examined potential causal relationships between weight, diet, or physical inactivity and risk of cancer. Overall, this literature has linked obesity to increased risk of several types of cancer, including colon, endometrial, kidney, and postmenopausal breast cancer [3-6]. A recent meta-analysis also concluded that insufficient physical activity increases the risk of breast or colon cancer [7]. It has been estimated that $15-20 \%$ of cancer deaths in the USA can be attributed to overweight and obesity [8], and in the European Union 5\% of cancer deaths may be related to overweight and obesity [9].

The mechanisms by which weight, diet, and physical activity influence tumor formation and progression are not completely understood. A number of putative physiological processes have been proposed. One hypothesis is that excess adipose tissue results in dysregulation of energy balance (i.e. the number of calories consumed and expended, as affected by physical activity, body size, fat and muscle, and genetics) and lipid metabolism affecting cytokine and growth factor levels (e.g. leptin, adiponectin, resistin and tumor necrosis factor alpha). These cytokines play a role in carcinogenesis [3]. Insulin and insulin-like growth factor 1 (IGF-1; once called somatomedin C) are also believed to be important. Intra-abdominal fat heightens insulin resistance, leading to increased pancreatic secretion of insulin. High concentrations of insulin reduce the synthesis of IGF-binding proteins 1 and 2, resulting in increased IGF-1 activity in the liver. This increased activity of insulin and IGF-1 reduces sex hormone binding globulin (SHBG) synthesis increasing testosterone and estradiol levels [10]. These conditions combine to influ-

\section{KARGER}

Fax +497614520714

Information@Karger.de

www.karger.com (c) 2009 S. Karger GmbH, Freiburg

Accessible online at:

www.karger.com/ofa 
ence cell proliferation and inhibition of apoptosis, especially in breast and endometrial tissues [11, 12]. Physical activity and maintenance of a normal body weight is thought to regulate these growth factor cytokines and SHBG, thus offering a potential protective effect against cancer [13-16]. Given the important role of hormones in the etiology of some cancers, these and other mechanisms continue to be investigated by basic and clinical scientists in the fields of endocrinology, metabolism, and oncology.

As is highlighted throughout this special issue of ОвеSITY FACTS, many energy balance-related behaviors establish themselves early in childhood and may track into adulthood. The period of childhood and growth into adolescence and early adulthood could represent a 'cumulative risk' for later adultonset cancers. 'Tracking' of behavioral risk is critical to understand in this context, in that it reflects the maintenance of a relative position in the population across time [17]. In our review, we attempt to understand the tracking of childhood weight, dietary behavior, and physical activity and its implications for cancer prevention. Thus, we review i) a large set of epidemiologic studies examining childhood and adolescent weight, diet, and physical activity as they relate to risk of adulthood cancers, and ii) discuss the implications for prevention and future directions.

\section{Methods}

This review is focused on peer-reviewed, published studies examining childhood and/or adolescent (up to age 18) exposures (specifically, body size, diet, physical activity) as they relate to adult cancer risk. We conducted multiple searches using the U.S. National Library of Medicine's online PubMed/MEDLINE interface, including root search terms and permutations such as 'child', 'adolescent', 'youth', 'obesity', 'adult', 'neoplasm', 'risk factor', 'observational study', 'cohort study', and 'prospective study'. Reference lists in identified studies and review papers were also culled for other relevant citations which were not identified via our original search. We excluded studies that focused primarily on maternal weight gain during pregnancy, pre-, peri-, and postnatal infant weight and the role of breastfeeding, achieved adult height only, or exposures that were assessed for ages older than 18 years. Although these are both important and relevant (as they have been associated with cancer risk), they were beyond the scope of this particular review. Table 1 presents a list of resulting studies, cataloged by risk (i.e. positive association with cancer) or protective (i.e. negative association with cancer) factor, and cancer type examined, including indicators of body size, diet, physical activity, adult cancer risk. These results are described and summarized in the narrative that follows.

\section{Weight and Cancer}

A total of 45 studies, conducted over the past 30 years, examining potential associations between childhood and adolescent weight on cancer risk were identified. A majority were casecontrol studies, with fewer nested case-control and retrospective cohort studies. A challenge in conducting this type of research is capturing the key exposure of interest, namely childhood and adolescent weight and height. A common method has been to ask individuals to self-report on their weight or body size relative to their peer group at certain ages [18-25]. Some studies used figure drawings depicting progressively larger body shapes as proxy measures of body size at certain age periods [26-30]. In some cases, studies assessed only weight at the late adolescent period, relying mainly on participants' retrospective recall of their weight during a period of adolescence, and current height was either self-reported or measured to calculate BMI [31-50]. Measured height and weight from childhood or adolescence were available in a small subset of studies [51-61]. These differences in methodology are important to note as they affect the quality of the evidence associated with each of the cancer types discussed below.

\section{Breast Cancer}

The association between childhood and adolescent body weight and breast cancer has received considerable attention: greater BMI at age 18, or higher perceived body fat relative to others during childhood, is associated with an approximately $20-50 \%$ decreased risk of breast cancer. This inverse association was reported among 22 studies; however, a small set indicted null findings when investigating the relationship between child indicators of weight and breast cancer [21, 35, 45, $47,48,52,57,60]$. Only one study found a positive (increased risk) relationship between the highest perceived weight category and breast cancer; that same study also reported an inverse relationship among those in the lowest weight category and risk of cancer relative to the average [19]. Many others found significant inverse associations mainly among women developing premenopausal breast cancer [26, 27, 29, 30, 41, $47,50,53,60,62,63]$. Studies examining different time periods in childhood found significant inverse associations for taller body size during the prepubertal stages [26, 60]. Among women with predominately postmenopausal breast cancer (or when data are stratified by menopausal status), no consistent association between adolescent weight or childhood body size and postmenopausal breast cancer risk emerges [28, 37, $47,60]$. Some studies do note that observed weight gain from late adolescence to adulthood increases risk of postmenopausal breast cancer [18, 28, 37, 39, 47]. Although there remains a possibility of misclassification of exposure due to reliance on adult retrospective recall of childhood size, four of the five studies that had measured height and weight data in childhood or adolescence observed an inverse relationship between BMI and breast cancer risk [53, 58, 60, 64]. 


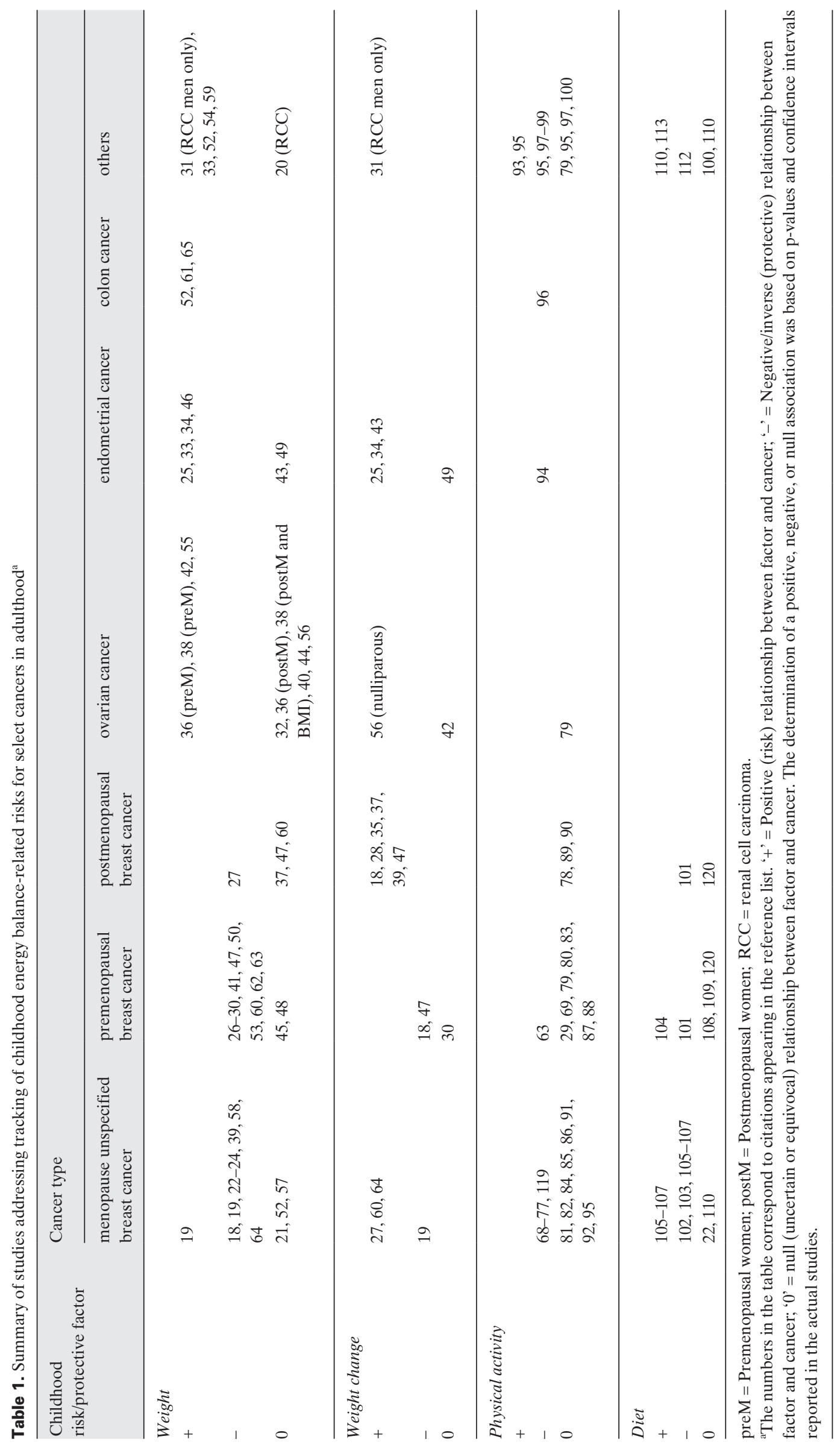




\section{Ovarian and Endometrial Cancer}

The relationship between child and adolescent weight and ovarian cancer has received less attention despite a plausible biological connection, as adiposity has been associated with some of the risk factors for ovarian cancer (e.g. ovulatory function, infertility, endometriosis, and inflammation) [56]. In eight recent studies, seven asked respondents to recall their weight at age 18 [32, 36, 38, 40, 42, 44, 56], and one measured height and weight available from age 14-17 years [55]. The results of these studies were mixed: four indicated a positive association between late adolescent BMI and risk of ovarian cancer [36, $38,42,55]$, and three reported a null or lack of association [32, $40,56]$. At least two of the studies showed risk may be more salient for premenopausal than for postmenopausal women $[36,38]$. The single nested case-control study observes a significant relative risk of adult ovarian cancer of 1.56 in those whose adolescent BMI was in the 85 th percentile (overweight range) compared to those women whose adolescent BMI was in the 25th-74th percentile (low normal range) [55].

Only nine studies of the relationship between body mass and endometrial cancer risk included measures of childhood or adolescent body mass. Most asked participants to recall their adolescent weight (ages 16-18) [25, 33, 34, 43, 46, 49] or rate it relative to others [25]: four indicated a positive association $[25,33,34,46]$, and one remained significant after adjusting for adult or current body mass [33]. Regarding weight gain, a single study found it to be a risk factor but only during the 4th decade of life [25]. Weight gain from 18 years of age was also a risk, mainly among women who were already overweight during adolescence [34].

\section{Colon and Renal Cancer}

Higher BMI has been associated with colon cancer in several epidemiologic studies; less is known about whether or not larger body mass (or greater BMI) in childhood and adolescence or change since adolescence confers greater risk. Studies indicate a positive association between larger body mass in youth and later adult colon cancer risk [52, 61, 65]. A recent study found a two-fold increase in risk of death from colon cancer related to $\mathrm{BMI}>85$ th percentile measured during adolescence [52]. In two studies of renal cancer, one found a weakly positive association with cancer risk among men related to retrospective report of BMI at age 18 [31]; another found no association between perceived body size at age 12 and renal cancer risk [20]. Adolescent weight may also moderate effects. Leaner adolescents with stable weight in adulthood have low risk, and markedly increased risk results with weight gain in adulthood [31]; heavy adolescents have elevated risk regardless of gain.

\section{Physical Activity and Cancer}

Several studies have examined the relationships between physical activity and breast [66] or endometrial cancers [67].
Both found evidence of reduced risk of breast and endometrial cancers with increased physical activity for adults though these trends are not necessarily reproduced for physical activity during childhood and adolescence $[66,67]$.

\section{Breast Cancer}

Significant risk reduction is observed among those who report being physically active as adolescents [68-77]. Participation in college athletics was associated with reduced risk of developing breast cancer [77] as well as breast and reproductive system cancers [76]. Modest risk reductions are also found among women reporting being physically active in their child and teen years $[78,79]$ or teen years only [80-82]. Eleven studies did not find an association between adolescent physical activity and breast cancer risk [29, 83-85] in the general population and in African-American women only [86]; no association with leisure or recreational activity [87-90], in relation to peers [91], or in a study where $<25 \%$ of the study population had been engaged in vigorous physical activity were reported [92].

\section{Other Cancers}

Studies examining the relationship between youth physical activity and other cancers were also reviewed and are evaluated together. Strenuous physical activity (e.g. activities that make individuals sweat or breathe hard) between the ages of 12-18 was associated with a significant reduction in risk for Hodgkin's lymphoma in women [93] as well as endometrial [94], rectal [95], colorectal [96], and renal cell cancer [97-99]. A single study showed a slightly reduced, but not significant trend for prostate cancer [100] - another found a significantly increased risk [95].

\section{Diet and Cancer}

Many studies focus on the relationship between the intake of different types of foods and nutrients and the development of cancer. These studies often examine contemporary dietary practices of adults. Diet and nutritional intake during childhood and adolescence has also been reported, and these works are summarized below.

\section{Breast Cancer}

Studies examining the relationship between child and adolescent diet and cancer have primarily focused on risk of breast cancer. Consumption of specific foods at various ages in women's lives have differentially reported associations with risk, making it difficult to draw clear and well-informed conclusions. A study that assessed diet both at cancer diagnosis and in adolescence found that among premenopausal women, high-fat foods (such as beef, pork, and gravy) increased risk, and consumption of fish decreased risk. In postmenopausal women only, pork consumption increased risk, and carrots decreased risk; none of these adult risk trends appeared in 
adolescence [22]. Today, pork (like chicken) is often bred and processed to be leaner than in the past - making some trimmed pork cuts now a lean meat.

Several researchers have examined the relationship between the consumption of specific food types or nutrients during childhood and their impact on the risk of breast cancer. Phytoestrogens (or dietary estrogens), which are found in foods such as soy, flaxseeds, grains, nuts, fruits and vegetables, reduced the risk of breast cancer when consumed during adolescence [101-103]. Eating red meat [104], butter [105], French fries [106], and a diet with a higher glycemic index (i.e. measured carbohydrate effects on blood glucose levels) [107] during childhood increased the risk of breast cancer. Conversely, decreased risk was associated with consumption of eggs, vegetable fat, fiber, and vitamin E (a known antioxidant) $[105,107]$. Moderately reduced risk may have been related to the consumption of fruits and vegetables [108] and milk [109], though benefits remain unproven in that context [110].

\section{Other Cancers}

In two studies using the same cohort [111], increased childhood fruit intake decreased risk of adult cancer [112], and increased childhood energy intake increased risk of adult cancer mortality [113]. Studies of childhood diet and prostate cancer risk have found either no association [100] or a slightly decreased but not significant risk with dairy consumption [110]. High dairy intake in childhood is associated with increased risk of colorectal cancer, but not associated with risk of stomach cancer [110].

\section{Limitations}

There are several limitations with this research, including the review's methodology and its studies reviewed. Though literature searches were thorough, some might have been incomplete. Capturing exposures of interest were also challenging, specifically childhood and adolescent body size and diet. Examining the association between childhood body size, diet or and physical activity and risk of adult cancer is limited in that recall over extended periods of time might be inaccurate. There is also the possibility of selection bias among controls who agreed to participate in research studies concerning physical activity; healthier and more physically active individuals may have been more likely to participate. Finally, measurement of physical activity and age ranges in which childhood physical activity was assessed differ across studies, making comparisons complex and challenging to interpret.

The major limitation to assessing the relationship between diet during early life and adult cancers is recall accuracy of foods consumed decades ago, although some focused on more specific and limited time periods. Limiting recall to a narrower time window, or focused only on the intake of a particular food, further affects this. Accuracy could be improved in future studies through assessment of childhood diet at the be- ginning of a prospective cohort study. Studies included in this review also relied on older cohorts, and it is not clear if associations hold up over time as populations become heavier, more sedentary, had different nutritional histories with increased consumption of processed foods (and differently processed foods) containing food additives.

\section{Prevention and Future Directions}

Cancer is the summation of different risks and exposures over the course of many years, including genetic susceptibility, environmental exposures, and modifiable risk factors. From birth to young adulthood, the human body is rapidly growing and developing, and exposures during this time period can be related to the development of cancer later in life [114]. As noted throughout this review, the implications of childhood overweight and obesity on future cancer risks accrued into adulthood are numerous and significant. As this evidence continues to mount from basic and clinical research investigations, the focus of our attention must ultimately turn toward prevention and intervention. From the standpoint of primary and secondary prevention of obesity, a recent review concludes that exercise and physical activity promotion are critical to achieving these ends [115]. We underscore the importance of these activities related to adult-onset cancers.

The World Health Organization has taken a strong stance on the prevention of obesity, noting its global health threat [116]. In the USA, the Institute of Medicine's Committee on Prevention of Obesity in Children and Youth developed a comprehensive strategy for America, detailing how key institutions in children's lives (families, schools, industry, communities, and government) can change the outcome of childhood obesity [117]. As the USA leads the world in its obesity epidemic, so too may it lead by example with respect to prevention. It is clear that the problem of childhood obesity must be viewed at the macro level, targeting the broad population of children. Until these goals are reached, a number of intermediate steps are also required. Chief among these are modifications to youth dietary and physical activity practices. As the evidence base for efficacious interventions in these areas continues to grow [118], so too will opportunities for interdisciplinary prevention interventions that address a more complete range of children's biopsychosocial risks and protections targeting obesity and cancer.

\section{Acknowledgement}

Preparation of this manuscript was partly supported by National Institutes of Health grants CA124905 to Dr. Fuemmeler and CA119686 to Dr. Tercyak.

\section{Disclosure}

The authors declared no conflict of interest. 


\section{References}

1 Ford ES, Mokdad AH: Epidemiology of obesity in the Western Hemisphere. J Clin Endocrinol Metab 2008;93(11 suppl 1):S1-8

2 The Challenge of Obesity in the WHO European Region and strategies for response. Summary. 2007 (cited December 23, 2008; available from: $w w w$. euro.who.int/eprise/main/who/InformationSources/ Publications/Catalogue/20070220_1).

$\checkmark 3$ Calle EE, Kaaks R: Overweight, obesity and cancer: epidemiological evidence and proposed mechanisms. Nat Rev Cancer 2004:4(8):579-591.

4 Chang, S., Mâsse LC, Moser RP, Dodd KW, Arganaraz F, Fuemmler BF, Jemal A: State ranks of incident cancer burden due to overweight and obesity in the United States, 2003. Obesity (Silver Spring) 2008;16(7):1636-1650.

5 Kaaks R, Lukanova A: Effects of weight control and physical activity in cancer prevention: role of endogenous hormone metabolism. Ann N Y Acad Sci 2002;963:268-281.

6 Vainio H, Kaaks R, Bianchini F: Weight control and physical activity in cancer prevention: international evaluation of the evidence. Eur J Cancer Prev 2002;11(suppl 2):S94-100.

7 Bull FC, Armstrong TP, Dixon T, Ham S, Neiman A, Pratt M: Physical inactivity; in Ezzati M, Lopes AD, Rodgers A, Murray CJL (eds): Comparative Quantification Of Health Risk: Global and Regional Burden of Diseases Attributable to Selected Major Risk Factors. Geneva, World Health Organization Press, 2004, pp 731-883.

$\checkmark 8$ Calle EE, Rodriguez C, Walker-Thurmond K, Thun MJ: Overweight, obesity, and mortality from cancer in a prospectively studied cohort of U.S. adults. N Engl J Med 2003;348(17):1625-1638.

$\checkmark 9$ Bergström A, Pisani P, Tenet V, Wolk A, Adami HO: Overweight as an avoidable cause of cancer in Europe. Int J Cancer 2001;91(3):421-430.

10 Bianchini F, Kaaks R, Vainio H: Overweight, obesity, and cancer risk. Lancet Oncol 2002;3(9):565-574.

11 Flötotto T, Djahansouzi S, Gläser M, Hanstein B, Niederacher D, Brumm C, Beckmann MW: Hormones and hormone antagonists: mechanisms of action in carcinogenesis of endometrial and breast cancer. Horm Metab Res 2001;33(8):451-457.

12 Key TJ, Pike MC: The role of oestrogens and progestagens in the epidemiology and prevention of breast cancer. Eur J Cancer Clin Oncol 1988;24(1): 29-43.

13 Haffner SM, Newcomb PA, Marcus PM, Klein BE, Klein R: Relation of sex hormones and dehydroepiandrosterone sulfate (DHEA-SO4) to cardiovascular risk factors in postmenopausal women. Am J Epidemiol 1995;142(9):925-934.

14 Sandhu MS, Dunger DB, Giovannucci EL: Insulin, insulin-like growth factor-I (IGF-I), IGF binding proteins, their biologic interactions, and colorectal cancer. J Natl Cancer Inst 2002;94(13):972-980.

15 Wei EK, Giovannucci E, Wu K, Rosner B, Fuchs CS, Willett WC, Colditz GA: Comparison of risk factors for colon and rectal cancer. Int J Cancer 2004;108(3):433-442.

16 Chan JM, Giovannucci E, Andersson SO, Yuen J, Adami HO, Wolk A: Dairy products, calcium, phosphorous, vitamin D, and risk of prostate cancer (Sweden). Cancer Causes Control 1998;9(6):559-566.

17 Twisk JW, Kemper HC, Mellenbergh GJ: Mathematical and analytical aspects of tracking. Epidemiol Rev 1994;16(2):165-183.

18 Brinton LA, Swanson CA: Height and weight at various ages and risk of breast cancer. Ann Epidemiol 1992;2(5):597-609.
Coates RJ, Uhler RJ, Hall HI, Potischman N, Brinton LA, Ballard-Barbash R, Gammon MD, Brogan DR, Daling JR, Malone KE, Schoenberg JB, Swanson CA: Risk of breast cancer in young women in relation to body size and weight gain in adolescence and early adulthood. Br J Cancer 1999;81(1): 167-174.

20 Dal Maso L, Zucchetto A, Tavani A, Montella M, Ramazzotti V, Talamini R, Canzonieri V, Garbeglio A, Negri E, Tonini A, La Vecchia C, Franceschi $\mathrm{S}$ : Renal cell cancer and body size at different ages: an Italian multicenter case-control study. Am J Epidemiol 2007;166(5):582-591.

21 Franceschi S, Favero A, La Vecchia C, Barón AE, Negri E, Dal Maso L, Giacosa A, Montella M, Conti E, Amadori D: Body size indices and breast cancer risk before and after menopause. Int J Cancer 1996; 67(2):181-186

22 Hislop TG, Coldman AJ, Elwood JM, Brauer G, Kan L: Childhood and recent eating patterns and risk of breast cancer. Cancer Detect Prev 1986;9(1-2): 47-58.

23 Liu L, Wu K, Lin X, Yin W, Zheng X, Tang X, Mu L, Hu Z, Wang J: Passive smoking and other factors at different periods of life and breast cancer risk in Chinese women who have never smoked - a casecontrol study in Chongqing, People's Republic of China. Asian Pac J Cancer Prev 2000;1(2):131-137.

24 Swerdlow AJ, De Stavola BL, Floderus B, Holm NV, Kaprio J, Verkasalo PK, Mack T: Risk factors for breast cancer at young ages in twins: an international population-based study. J Natl Cancer Inst 2002;94(16):1238-1246.

$25 \mathrm{Xu}$ WH, Xiang YB, Zheng W, Zhang X, Ruan ZX, Cheng JR, Gao YT, Shu XO: Weight history and risk of endometrial cancer among Chinese women. Int J Epidemiol 2006;35(1):159-166.

26 Baer HJ, Colditz GA, Rosner B, Michels KB, RichEdwards JW, Hunter DJ, Willett WC: Body fatness during childhood and adolescence and incidence of breast cancer in premenopausal women: a prospective cohort study. Breast Cancer Res 2005;7(3): R314-325.

27 Berkey CS, Frazier AL, Gardner JD, Colditz GA: Adolescence and breast carcinoma risk. Cancer 1999;85(11):2400-2409.

28 Magnusson C, Baron J, Persson I, Wolk A, Bergström R, Trichopoulos D, Adami HO: Body size in different periods of life and breast cancer risk in postmenopausal women. Int J Cancer 1998;76(1):29-34.

29 Magnusson CM, Roddam AW, Pike MC, Chilvers C, Crossley B, Hermon C, McPherson K, Peto J, Vessey M, Beral V: Body fatness and physical activity at young ages and the risk of breast cancer in premenopausal women. Br J Cancer 2005;93(7): 817-824.

30 Weiderpass E, Braaten T, Magnusson C, Kumle M, Vainio H, Lund E, Adami HO: A prospective study of body size in different periods of life and risk of premenopausal breast cancer. Cancer Epidemiol Biomarkers Prev 2004;13(7):1121-1127.

31 Adams KF, Leitzmann MF, Albanes D, Kipnis V, Moore SC, Schatzkin A, Chow WH: Body size and renal cell cancer incidence in a large US cohort study. Am J Epidemiol 2008;168(3):268-277.

32 Anderson JP, Ross JA, Folsom AR: Anthropometric variables, physical activity, and incidence of ovarian cancer: The Iowa Women's Health Study. Cancer 2004;100(7):1515-1521.

33 Blitzer PH, Blitzer EC, Rimm AA: Association between teen-age obesity and cancer in 56,111 women: all cancers and endometrial carcinoma. Prev Med 1976;5(1):20-31.
4 Chang SC, Lacey JV Jr, Brinton LA, Hartge P, Adams K, Mouw T, Carroll L, Hollenbeck A, Schatzkin A, Leitzmann MF: Lifetime weight history and endometrial cancer risk by type of menopausal hormone use in the NIH-AARP diet and health study. Cancer Epidemiol Biomarkers Prev 2007; 16(4):723-730.

35 Chu SY, Lee NC, Wingo PA, Senie RT, Greenberg RS, Peterson HB: The relationship between body mass and breast cancer among women enrolled in the Cancer and Steroid Hormone Study. J Clin Epidemiol 1991;44(11):1197-1206.

36 Fairfield KM, Willett WC, Rosner BA, Manson JE, Speizer FE, Hankinson SE: Obesity, weight gain and ovarian cancer. Obstet Gynecol 2002;100(2): 288-296.

37 Folsom AR, Kaye SA, Prineas RJ, Potter JD, Gapstur SM, Wallace RB: Increased incidence of carcinoma of the breast associated with abdominal adiposity in postmenopausal women. Am J Epidemiol 1990;131(5):794-803

38 Hoyo C, Berchuck A, Halabi S, Bentley RC, Moorman P, Calingaert B, Schildkraut JM: Anthropometric measurements and epithelial ovarian cancer risk in African-American and White women. Cancer Causes Control 2005;16(8):955-963.

39 Huang Z, Hankinson SE, Colditz GA, Stampfer MJ, Hunter DJ, Manson JE, Hennekens CH Rosner B, Speizer FE, Willett WC: Dual effects of weight and weight gain on breast cancer risk. JAMA 1997;278(17):1407-1411.

40 Kuper H, Cramer DW, Titus-Ernstoff L: Risk of ovarian cancer in the United States in relation to anthropometric measures: does the association depend on menopausal status? Cancer Causes Control 2002;13(5):455-463.

41 London SJ, Colditz GA, Stampfer MJ, Willett WC Rosner B, Speizer FE: Prospective study of relative weight, height, and risk of breast cancer. JAMA 1989;262(20):2853-2858.

42 Lubin F, Chetrit A, Freedman LS, Alfandary E, Fishler Y, Nitzan H, Zultan A, Modan B: Body mass index at age 18 years and during adult life and ovarian cancer risk. Am J Epidemiol 2003;157(2): 113-120.

43 Olson SH, Trevisan M, Marshall JR, Graham S, Zielezny M, Vena JE, Hellmann R, Freudenheim JL: Body mass index, weight gain, and risk of endometrial cancer. Nutr Cancer 1995;23(2):141-149.

44 Rossing MA, Tang MT, Flagg EW, Weiss LK, Wicklund KG, Weiss NS: Body size and risk of epithelial ovarian cancer (United States). Cancer Causes Control 2006;17(5):713-720.

45 Sanderson M, Shu XO, Jin F, Dai Q, Ruan Z, Gao YT, Zheng W: Weight at birth and adolescence and premenopausal breast cancer risk in a low-risk population. Br J Cancer 2002;86(1):84-88.

46 Swanson CA, Potischman N, Wilbanks GD, Twiggs LB, Mortel R, Berman ML, Barrett RJ, Baumgartner RN, Brinton LA: Relation of endometrial cancer risk to past and contemporary body size and body fat distribution. Cancer Epidemiol Biomarkers Prev 1993;2(4):321-327.

47 Trentham-Dietz A, Newcomb PA, Storer BE, Longnecker MP, Baron J, Greenberg ER, Willett WC: Body size and risk of breast cancer. Am J Epidemiol 1997;145(11):1011-1019.

48 Ursin G, Paganini-Hill A, Siemiatycki J, Thompson WD, Haile RW: Early adult body weight, body mass index, and premenopausal bilateral breast cancer: data from a case-control study. Breast Cancer Res Treat 1995;33(1):75-82. 
49 Weiderpass E, Persson I, Adami HO, Magnusson C, Lindgren A, Baron JA: Body size in different periods of life, diabetes mellitus, hypertension, and risk of postmenopausal endometrial cancer (Sweden). Cancer Causes Control 2000;11(2):185-192.

50 Willett WC, Browne ML, Bain C, Lipnick RJ, Stampfer MJ, Rosner B, Colditz GA, Hennekens $\mathrm{CH}$, Speizer FE: Relative weight and risk of breast cancer among premenopausal women. Am J Epidemiol 1985;122(5):731-740.

51 Engeland A, Bjørge T, Søgaard AJ, Tverdal A: Body mass index in adolescence in relation to tota mortality: 32-year follow-up of 227,000 Norwegian boys and girls. Am J Epidemiol 2003;157(6):517523.

\$52 Bjørge T, Engeland A, Tverdal A, Smith GD: Body mass index in adolescence in relation to cause-specific mortality: a follow-up of 230,000 Norwegian adolescents. Am J Epidemiol 2008;168(1):30-37.

53 De Stavola BL, dos Santos Silva I, McCormack V, Hardy RJ, Kuh DJ, Wadsworth ME: Childhood growth and breast cancer. Am J Epidemiol 2004; 159(7):671-682.

54 DiPietro L, Mossberg HO, Stunkard AJ: A 40-year history of overweight children in Stockholm: lifetime overweight, morbidity, and mortality. Int J Obes Relat Metab Disord 1994;18(9):585-590.

55 Engeland A, Tretli S, Bjørge T: Height, body mass index, and ovarian cancer: a follow-up of 1.1 million Norwegian women. J Natl Cancer Inst 2003;95(16): 1244-1248.

56 Greer JB, Modugno F, Ness RB, Allen GO: Anthropometry and the risk of epithelial ovarian cancer. Cancer 2006;106(10):2247-2257.

57 Herrinton LJ, Husson G: Relation of childhood height and later risk of breast cancer. Am J Epidemiol 2001;154(7):618-623.

58 Hilakivi-Clarke L, Forsén T, Eriksson JG, Luoto R, Tuomilehto J, Osmond C, Barker DJ: Tallness and overweight during childhood have opposing effects on breast cancer risk. Br J Cancer 2001;85(11):1680-1684

59 Jeffreys M, Smith GD, Martin RM, Frankel S, Gunnell D: Childhood body mass index and later cancer risk: a 50-year follow-up of the Boyd Orr study. Int J Cancer 2004;112(2):348-351.

60 Le Marchand L, Kolonel LN, Earle ME, Mi MP: Body size at different periods of life and breast cancer risk. Am J Epidemiol 1988;128(1):137-152.

61 Must A, Jacques PF, Dallal GE, Bajema CJ, Dietz WH: Long-term morbidity and mortality of overweight adolescents. A follow-up of the Harvard Growth Study of 1922 to 1935. N Engl J Med 1992;327(19):1350-1355.

62 Ahlgren M, Wohlfahrt J, Olsen LW, Sørensen TI, Melbye M: Birth weight and risk of cancer. Cancer 2007;110(2):412-419.

63 Baer HJ, Schnitt SJ, Connolly JL, Byrne C, Willett WC, Rosner B, Colditz GA: Early life factors and incidence of proliferative benign breast disease. Cancer Epidemiol Biomarkers Prev 2005;14(12):2889-2897.

64 Ahlgren M, Melbye M, Wohlfahrt J, Sørensen TI: Growth patterns and the risk of breast cancer in women. Int J Gynecol Cancer 2006;16(suppl 2): 569-575.

65 Le Marchand L, Wilkens LR, Mi MP: Obesity in youth and middle age and risk of colorectal cancer in men. Cancer Causes Control 1992;3(4):349-354.

66 Friedenreich CM, Cust AE: Physical activity and breast cancer risk: impact of timing, type and dose of activity and population subgroup effects. $\mathrm{Br} \mathrm{J}$ Sports Med 2008;42(8):636-647.
67 Voskuil DW, Monninkhof EM, Elias SG, Vlems FA, van Leeuwen FE; Task Force Physical Activity and Cancer: Physical activity and endometrial cancer risk, a systematic review of current evidence. Cancer Epidemiol Biomarkers Prev 2007;16(4): 639-648.

68 D'Avanzo B, Nanni O, La Vecchia C, Franceschi S, Negri E, Giacosa A, Conti E, Montella M, Talamini R, Decarli A: Physical activity and breast cancer risk. Cancer Epidemiol Biomarkers Prev 1996; 5(3):155-160.

69 Dorn J, Vena J, Brasure J, Freudenheim J, Graham S: Lifetime physical activity and breast cancer risk in pre- and postmenopausal women. Med Sci Sports Exerc,2003;35(2):278-285.

70 Marcus PM, Newman B, Moorman PG, Millikan RC, Baird DD, Qaqish B, Sternfeld B: Physical activity at age 12 and adult breast cancer risk (United States). Cancer Causes Control 1999;10(4):293302

71 Matthews CE, Shu XO, Jin F, Dai Q, Hebert JR, Ruan ZX, Gao YT, Zheng W: Lifetime physical activity and breast cancer risk in the Shanghai Breast Cancer Study. Br J Cancer 2001;84(7):994-1001.

72 Mittendorf R, Longnecker MP, Newcomb PA, Dietz AT, Greenberg ER, Bogdan GF, Clapp RW, Willett WC: Strenuous physical activity in young adulthood and risk of breast cancer (United States). Cancer Causes Control 1995;6(4):347-353.

73 Shoff SM, Newcomb PA, Trentham-Dietz A, Remington PL, Mittendorf R, Greenberg ER, Willett WC: Early-life physical activity and postmenopausal breast cancer: effect of body size and weight change. Cancer Epidemiol Biomarkers Prev 2000;9(6):591-595.

74 Slattery ML, Edwards S, Murtaugh MA, Sweeney C, Herrick J, Byers T, Giuliano AR, Baumgartner KB: Physical activity and breast cancer risk among women in the southwestern United States. Ann Epidemiol 2007;17(5):342-353.

75 Verloop J, Rookus MA, van der Kooy K, van Leeuwen FE: Physical activity and breast cancer risk in women aged 20-54 years. J Natl Cancer Inst 2000;92(2):128-135

76 Frisch RE, Wyshak G, Albright NL, Albright TE, Schiff I, Jones KP, Witschi J, Shiang E, Koff E, Marguglio M: Lower prevalence of breast cancer and cancers of the reproductive system among former college athletes compared to non-athletes. Br J Cancer 1985;52(6):885-891.

77 Wyshak G, Frisch RE: Breast cancer among former college athletes compared to non-athletes: a 15year follow-up. Br J Cancer 2000;82(3):726-730.

78 Friedenreich CM, Courneya KS, Bryant HE: Influence of physical activity in different age and life periods on the risk of breast cancer. Epidemiology 2001;12(6):604-12.

79 Pukkala E, Poskiparta M, Apter D, Vihko V: Lifelong physical activity and cancer risk among Finnish female teachers. Eur J Cancer Prev 1993;2(5):369376.

$80 \mathrm{Hu}$ YH, Nagata C, Shimizu H, Kaneda N, Kashiki $\mathrm{Y}$ : Association of body mass index, physical activity, and reproductive histories with breast cancer: a case-control study in Gifu, Japan. Breast Cancer Res Treat 1997;43(1):65-72.

81 McTiernan A, Kooperberg C, White E, Wilcox S, Coates R, Adams-Campbell LL, Woods N, Ockene J; Women's Health Initiative Cohort Study: Recreational physical activity and the risk of breast cancer in postmenopausal women: the Women's Health Initiative Cohort Study. JAMA 2003; 290(10):1331-1336.
82 Sprague BL, Trentham-Dietz A, Newcomb PA, Titus-Ernstoff L, Hampton JM, Egan KM: Lifetime recreational and occupational physical activity and risk of in situ and invasive breast cancer. Cancer Epidemiol Biomarkers Prev 2007;16(2):236-243.

83 Margolis KL, Mucci L, Braaten T, Kumle M, Trolle Lagerros Y, Adami HO, Lund E, Weiderpass E Physical activity in different periods of life and the risk of breast cancer: the Norwegian-Swedish Women's Lifestyle and Health cohort study. Cancer Epidemiol Biomarkers Prev 2005;14(1):27-32.

84 Moradi T, Nyrén O, Zack M, Magnusson C, Persson I, Adami HO: Breast cancer risk and lifetime leisure-time and occupational physical activity (Sweden). Cancer Causes Control 2000;11(6):523529.

85 Steindorf K, Schmidt M, Kropp S, Chang-Claude $\mathrm{J}$ : Case-control study of physical activity and breast cancer risk among premenopausal women in Germany. Am J Epidemiol 2003;157(2):121-130.

86 Adams-Campbell LL, Rosenberg L, Rao RS, Palmer JR: Strenuous physical activity and breast cancer risk in African-American women. J Natl Med Assoc 2001;93(7-8):267-275.

87 Chen CL, White E, Malone KE, Daling JR: Leisure-time physical activity in relation to breast cancer among young women (Washington, United States). Cancer Causes Control 1997;8(1):77-84.

88 Gammon MD, Schoenberg JB, Britton JA, Kelsey JL, Coates RJ, Brogan D, Potischman N, Swanson CA, Daling JR, Stanford JL, Brinton LA: Recreational physical activity and breast cancer risk among women under age 45 years. Am J Epidemiol 1998;147(3):273-280.

89 Lee IM, Cook NR, Rexrode KM, Buring JE: Lifetime physical activity and risk of breast cancer. $\mathrm{Br} \mathrm{J}$ Cancer 2001;85(7):962-965

90 McTiernan A, Stanford JL, Weiss NS, Daling JR, Voigt LF: Occurrence of breast cancer in relation to recreational exercise in women age 50-64 years. Epidemiology 1996;7(6):598-604.

91 Kruk J, Aboul-Enein HY: Physical activity in the prevention of cancer. Asian Pac J Cancer Prev 2006;7(1):11-21

92 Taioli E, Barone J, Wynder EL: A case-control study on breast cancer and body mass. The American Health Foundation - Division of Epidemiology. Eur J Cancer 1995;31A(5):723-728.

93 Keegan TH, Glaser SL, Clarke CA, Dorfman RF, Mann RB, DiGiuseppe JA, Chang ET, Ambinder RF: Body size, physical activity, and risk of Hodgkin's lymphoma in women. Cancer Epidemiol Biomarkers Prev 2006;15(6):1095-1101.

94 Olson SH, Vena JE, Dorn JP, Marshall JR, Zielezny M, Laughlin R, Graham S: Exercise, occupational activity, and risk of endometrial cancer. Ann Epidemiol 1997;7(1):46-53.

95 Paffenbarger RS Jr, Hyde RT, Wing AL: Physical activity and incidence of cancer in diverse populations: a preliminary report. Am J Clin Nutr 1987;45(1 suppl):312-317.

96 Levi F, Pasche C, Lucchini F, Tavani A, La Vecchia C: Occupational and leisure-time physical activity and the risk of colorectal cancer. Eur J Cancer Prev 1999;8(6):487-93.

97 Menezes RJ, Tomlinson G, Kreiger N: Physical activity and risk of renal cell carcinoma. Int J Cancer 2003;107(4):642-646.

98 Moore SC, Chow WH, Schatzkin A, Adams KF, Park Y, Ballard-Barbash R, Hollenbeck A, Leitzmann MF: Physical activity during adulthood and adolescence in relation to renal cell cancer. Am J Epidemiol 2008;168(2):149-157. 
-99 Tavani A, Zucchetto A, Dal Maso L, Montella M, Ramazzotti V, Talamini R, Franceschi S, La Vecchia C: Lifetime physical activity and the risk of renal cell cancer. Int J Cancer 2007;120(9):19771980.

100 Andersson SO, Baron J, Wolk A, Lindgren C, Bergström R, Adami HO: Early life risk factors for prostate cancer: a population-based case-control study in Sweden. Cancer Epidemiol Biomarkers Prev 1995;4(3):187-192.

-101 Shu XO, Jin F, Dai Q, Wen W, Potter JD, Kushi LH, Ruan Z, Gao YT, Zheng W: Soyfood intake during adolescence and subsequent risk of breast cancer among Chinese women. Cancer Epidemiol Biomarkers Prev 2001;10(5):483-488.

-102 Thanos J, Cotterchio M, Boucher BA, Kreiger N, Thompson LU: Adolescent dietary phytoestrogen intake and breast cancer risk (Canada). Cancer Causes Control 2006;17(10):1253-1261.

103 Wu AH, Wan P, Hankin J, Tseng CC, Yu MC, Pike MC: Adolescent and adult soy intake and risk of breast cancer in Asian-Americans. Carcinogenesis 2002;23(9):1491-1496.

104 Linos E, Willett WC, Cho E, Colditz G, Frazier LA: Red meat consumption during adolescence among premenopausal women and risk of breast cancer. Cancer Epidemiol Biomarkers Prev 2008; 17(8):2146-2151.

105 Frazier AL, Ryan CT, Rockett H, Willett WC, Colditz GA: Adolescent diet and risk of breast cancer. Breast Cancer Res 2003;5(3):R59-64.
106 Michels KB, Rosner BA, Chumlea WC, Colditz GA, Willett WC: Preschool diet and adult risk of breast cancer. Int J Cancer 2006;118(3):749-754.

107 Frazier AL, Li L, Cho E, Willett WC, Colditz GA: Adolescent diet and risk of breast cancer. Cancer Causes Control 2004;15(1):73-82.

108 Potischman N, Weiss HA, Swanson CA, Coates RJ, Gammon MD, Malone KE, Brogan D, Stanford JL, Hoover RN, Brinton LA: Diet during adolescence and risk of breast cancer among young women. J Natl Cancer Inst 1998;90(3):226-233.

109 Hjartaker A, Laake P, Lund E: Childhood and adult milk consumption and risk of premenopausal breast cancer in a cohort of 48,844 women - the Norwegian women and cancer study. Int J Cancer 2001;93(6):888-893.

110 van der Pols JC, Bain C, Gunnell D, Smith GD, Frobisher C, Martin RM: Childhood dairy intake and adult cancer risk: 65-y follow-up of the Boyd Orr cohort. Am J Clin Nutr 2007;86(6):17221729.

111 Gunnell DJ, Frankel S, Nanchahal K, Braddon FE, Smith GD: Lifecourse exposure and later disease: a follow-up study based on a survey of family diet and health in pre-war Britain (1937-1939). Public Health 1996;110(2):85-94.

112 Maynard M, Gunnell D, Emmett P, Frankel S, Davey Smith G: Fruit, vegetables, and antioxidants in childhood and risk of adult cancer: the Boyd Orr cohort. J Epidemiol Community Health 2003;57(3):218-225.
113 Frankel S, Gunnell DJ, Peters TJ, Maynard M, Davey Smith G: Childhood energy intake and adult mortality from cancer: the Boyd Orr Cohort Study. BMJ 1998;316(7130):499-504.

114 Tercyak KP, Tyc VL: Opportunities and challenges in the prevention and control of cancer and other chronic diseases: children's diet and nutrition and weight and physical activity. J Pediatr Psychol 2006;31(8):750-763.

115 Dugan SA: Exercise for preventing childhood obesity. Phys Med Rehabil Clin N Am 2008;19(2): 205-216, vii.

116 Obesity: Preventing and Managing the Global Epidemic. Report of a WHO Consultation. World Health Organ Tech Rep Ser, 2000;894:i-xii, 1-253.

117 Preventing Childhood Obesity: Health in the Balance. 2005 (cited December 12, 2008; available from: www.nap.edu/catalog.php?record_id = 11015\#toc).

118 Estabrooks PA, Fisher EB, Hayman LL: What is needed to reverse the trends in childhood obesity? a call to action. Ann Behav Med 2008; 36(3):209-216

119 Levi F, Pasche C, Lucchini F, La Vecchia C: Occupational and leisure time physical activity and the risk of breast cancer. Eur J Cancer 1999; 35(5):775-778.

120 Pryor M, Slattery ML, Robison LM, Egger M: Adolescent diet and breast cancer in Utah. Cancer Res 1989;49(8):2161-2167. 